\title{
Multiple Objective and Span Evaluation Method for Damage Grade of Existing Reinforced Concrete Bridges
}

Ming-Te Liang

Professor, Department of Harbor and River Engineering, National Taiwan Ocean University, Keelung, Taiwan 20224, China

Heng-Dong Wang

Senior Engineering, The Second Department of Water Supply and Drainage, Shanghai Municipal Engineering Design and Research Institute, Shanghai 200092, China

Jai-He Wu

Graduate Student, Department of Harbor and River Engineering, National Taiwan Ocean University, Keelung, Taiwan 20224, China

Follow this and additional works at: https://jmstt.ntou.edu.tw/journal

Part of the Civil and Environmental Engineering Commons

\section{Recommended Citation}

Liang, Ming-Te; Wang, Heng-Dong; and Wu, Jai-He (2001) "Multiple Objective and Span Evaluation Method for Damage Grade of Existing Reinforced Concrete Bridges," Journal of Marine Science and Technology. Vol. 9: Iss. 2, Article 9.

DOI: $10.51400 / 2709-6998.2444$

Available at: https://jmstt.ntou.edu.tw/journal/vol9/iss2/9

This Research Article is brought to you for free and open access by Journal of Marine Science and Technology. It has been accepted for inclusion in Journal of Marine Science and Technology by an authorized editor of Journal of Marine Science and Technology. 


\section{Multiple Objective and Span Evaluation Method for Damage Grade of Existing}

Reinforced Concrete Bridges

\section{Acknowledgements}

The authors would like to thank to the National Science Council of the R. O. C. for financial support of this study under Contract NSC 89-2211-E-019-015. 


\title{
MULTIPLE OBJECTIVE AND SPAN EVALUATION METHOD FOR DAMAGE GRADE OF EXISTING REINFORCED CONCRETE BRIDGES
}

\author{
Ming-Te Liang*, Heng-Dong Wang** and Jai-He $\mathrm{Wu}^{* * *}$
}

Keywords: evaluation grade, damage degree, membership, weight.

\begin{abstract}
The principal purpose of this paper was to investigate the evaluation method of performance for existing reinforced concrete bridges. The least squares technique in classical mathematics was adopted firmly to establish both the multiple objective weight distribution method and multiple span level weight method. Thus, the multiple objective and span evaluation method were built for estimating the performance of existing reinforced concrete bridges. The evaluation model may be divided into grades I, II, III and IV which are described as non-damage, light damage, severe damage and unfit for service, respectively. Using the proposed model, the Huey-tong bridge, Jzyhchyang bridge, Ay-gow west road viaduct and old Hwan-nan viaduct in Taipei were chosen for evaluation. The evaluated results of the present investigation indicate that four existing bridges all belong to grade II. If periodic small scale repair and reinforcement are carried out, then the four bridges can be continuously used. The order of repair and reinforcement is the Huey-tong bridge, Ay-gow west road viaduct, old Hwan-nan viaduct and Jzyh-chyang bridge. Thus, the multiple objective and span evaluation method appears to be advantageous for evaluating the damage grade of existing reinforced concrete bridges. The results of this study were provided as a basis for repair, reinforcement, and demolition of existing reinforced concrete bridges.
\end{abstract}

\section{INTRODUCTION}

At present, many researchers all over the world are engaged in the investigation of reliable performance evaluation methods for existing structures or members. They also acquired achievement. Following the development of scientific techniques and the creation of new types of building materials with high strength, the system of building structure varies more intricately. As a

Paper Received Oct. 1, 2001. Author for Correspondence: Ming-Te Liang. *Professor, Department of Harbor and River Engineering, National Taiwan Ocean University, Keelung, Taiwan 20224, China

**Senior Engineering, The Second Department of Water Supply and Drainage, Shanghai Municipal Engineering Design and Research Institute, Shanghai 200092, China

***Graduate Student, Department of Harbor and River Engineering, National Taiwan Ocean University, Keelung, Taiwan 20224, China result, the evaluation of corresponding existing structure is again a complex evaluation system with multiple objectives and criterion. Especially, the usage performance of some important civil and hydraulic engineering structures is evaluated. Regarding the people who put this in practice, they encounter much more difficulty. In the case of complicated structural systems, the differently composed members will have interactive influences, interactive constraints, plethoric randomness, and fuzzy information. The evaluation task is changed as the problem that is one of half quantification or nonquantification. Consequently, the development of new evaluation methods is needed.

After Zadeh (1965) published fuzzy sets, fuzzy mathematics has been used extensively in numerous investigations. In computational science, the use of fuzzy mathematics was also developed for use in the field of human natural mechanism. Zadeh [1978] pointed out that the mathematical apparatus of the theory of fuzzy sets provides a natural basis for playing a role which is similar to that of measure theory in the theory of probability. Viewed in this perspective, a fuzzy restriction may be interpreted as a possibility distribution with its membership function playing the role of a possibility distribution function. A fuzzy variable is associated with a possibility distribution in much the same manner as a random variable is associated with a probability distribution. Zadeh (1979) indicated that fuzzy reasoning is the process by which a possibly imprecise conclusion is deduced from a collection of imprecise premises. Such reasoning is, for the most part, qualitative rather than quantitative in nature, and nearly all of it falls outside of the domain of classical logic. Yao (1979) used the concept of structural identification to perform damage assessment and reliability evaluations on existing structures. Yao (1985) presented the theory of fuzzy sets as useful in interpreting the safety and reliability of existing structures with membership functions, which can be manipulated in a logical manner to obtain an answer to the original complex problem. Tharmabala and Nowak (1987) used mathematical models that can conveniently represent a 
bridge structure using a suitable structure function and (or) reliability network. By introducing the concept of probability into the structural function and (or) reliability network, it is possible to evaluate a bridge system reliability. The system reliability of a structure with selected component failures can also be evaluated in a fashion similar to a structure without component failures except that the component reliability is adjusted to account for the load redistribution. Tee et al. (1988) and Tee (1988) adopted fuzzy mathematics to provide a cumulative rating function method for evaluating bridges. Shiaw and Huang (1990) used the weight limit state design principle to determine the bearing capacity index and safety of a bridge through the synthesis of fuzzy evaluation and random analysis. Jwu et al. (1991) provided the grade method through fuzzy mathematics to evaluate harbor wharf engineering reliability for enhancing evaluation performance. Qian (1992) used the concept of fuzzy sets to evaluate the damage grade of existing bridges. Wang (1992) introduced fuzzy synthesis evaluation theories with single, and multiple factors, double- and multiple-layers and their applications in earthquake models. Mori and Ellingwood (1993) used a reliability-based method to evaluate the service life of aging concrete structures. Mori and Ellingwood (1994a, 1994b) used a Bayesian analysis to study the remaining reliability of a concrete structure during a projected service period involving the randomness in existing damage and in damage detection. Moses et al. (1994) adopted bridge-testing methods to evaluate bridge safety. Qu (1995) adopted fuzzy probability for studying the durability evaluation for existing concrete bridges with cracks. Wang (1996) provided a multitarget and multiperson evaluation method for existing structural durability. Zhao (1996) provided a reliability analysis and fuzzy evaluation for the safety of existing structures and established a relative evaluation method. Liang et al. (2000) adopted double-layer fuzzy evaluation method to evaluate the membership degree of existing reinforced concrete bridges in Taipei. Liang et al. (2001) used multiple-layer fuzzy evaluation method to determine the damage grade of existing reinforced concrete bridges in Taipei. To date, however, no studies have attempted to evaluate the damage state of existing reinforced concrete bridges without employing multiple objectives and span evaluation method. This is a notable defect, because the use of multiple objectives and span evaluation method is useful for assessing the damage grade of existing reinforced concrete bridges.

The principal purpose of this investigation was to use the concept of fuzzy mathematics to build a damage evaluation method for existing reinforced concrete bridges. Based on the concept, basic property, and determination method of weight, the evaluation grade method with multiple objective and span was provided for the existing reinforced concrete bridges. The results of this investigation may help to offer a basis for repair, reinforcement, and demolition of existing reinforced concrete bridges.

\section{MULTIPLE OBJECTIVE AND SPAN EVLUATION METHOD}

\section{Evaluation objective weight determination method}

Suppose that the $m$ evaluation members of a bridge are carried out damage evaluation with respect to $n$ objectives regarding a structural system needed for evaluation. Then the characteristic weight matrix with $m$ by $n$ is

$$
A=\left[\begin{array}{cccc}
a_{11} & a_{12} & \cdots & a_{1 n} \\
a_{21} & a_{22} & \cdots & a_{2 n} \\
\vdots & \vdots & \ddots & \vdots \\
a_{m 1} & a_{m 2} & \cdots & a_{m n}
\end{array}\right]
$$

where $a_{i j}$ represents the damage evaluation index of the ith evaluation members with respect to the jth damage evaluation items. The value of $a_{i j}$ satisfies $0 \leq a_{i j} \leq 1$, where $i=1,2, \ldots, m$ and $j=1,2, \ldots, n$. We also stipulate that if the index value of $a_{i j}$ is large, then the damage degree is more severe.

Owing to the total value of every evaluation member, that is $a_{11}+a_{12}+\ldots+a_{1 n} \neq a_{21}+a_{22}+\ldots+a_{2 n}$ $\neq a_{m 1}+a_{m 2}+\ldots+a_{m n}$, when the damage evaluation is performed, the weight value of damage evaluation of every evaluation item carried out with every evaluation member should be normalized as

$$
B=\left[\begin{array}{cccc}
b_{11} & b_{12} & \cdots & b_{1 n} \\
b_{21} & b_{22} & \cdots & b_{2 n} \\
\vdots & \vdots & \ddots & \vdots \\
b_{m 1} & b_{m 2} & \cdots & b_{m n}
\end{array}\right]
$$

where

$$
b_{i j}=\frac{a_{i j}}{\sum_{j=1}^{n} a_{i j}}
$$

The value of $b_{i j}$ also satisfies $0 \leq b_{i j} \leq 1$ and $\sum_{j=1}^{n} b_{i j}=1$.

In relation to the damage evaluation item of $n$ numbers, the best relative weight should objectively exist. Assume that

$$
W=\left(w_{1}, w_{2}, \ldots, w_{n}\right)
$$

is the optimum weight vector of evaluation item with $n$ number in structural damage evaluation system. The concept of generalized distance in mathematics is 
adopted and is described as

$$
D=\|B-W\|^{2}=\left[\sum_{i=1}^{m} \sum_{j=1}^{n}\left(b_{i j}-w_{j}\right)^{P}\right]^{2 / P}
$$

In order to conveniently and easily find the optimum weight function from Eq. (5), we take $p=2$ and seek the derivatives of $D$ with respect to variables $w_{i}$. In addition, putting $\frac{\partial D}{\partial w_{j}}=0 \quad(j=1,2, \ldots, n)$, that is

$$
\frac{\partial D}{\partial w_{j}}=2 \sum_{i}^{m} w_{j}-2 \sum_{i=1}^{m} b_{i j}=0
$$

we obtain

$$
w_{j}=\frac{\sum_{i}^{m} b_{i j}}{m}, \quad(j=1,2, \ldots, n)
$$

Equation (6) denotes that $w_{j}$ is the arithmetic mean of $b_{i j}$, where $i=1,2, \ldots, m$.

\section{Level weight determination method of every evalua- tion member}

Since every evaluation member of a bridge is different and is subjected to different force, even the same evaluation member such as girder, both the damage degree and forced situation are all different if the member with the same name is located at a different span. Therefore, in the evaluation process of damage situation of a bridge, one is firmly established as the relative weight of every evaluation item, the other is needed to determine the relative weight among every evaluation item. Generally speaking, the fastest and most convenient method of treating the late ones is to compute an average for them, that is,

$$
\lambda_{i}=\frac{1}{m}, \quad(i=1,2, \ldots, m)
$$

where $m$ denotes that the bridge is divided into evaluation item with $m$ numbers and $\lambda_{i}$ represents the relative weight of the $i$-th evaluation item.

How to determine the relative weight of every evaluation item, based on the data of existing evaluation members, is worthy to study in depth. When the evaluation item is divided in more detail, the weight ratio of every item is correspondingly disunited. Consequently, the importance between items result in decreasing. The evaluation task is impossible to perform with reasonability and objectivity.

For the purpose of solving the above problem, the least squares technique in mathematics is herein adopted. According to the actual evaluation results of different evaluation items and the different levels of the optimum weight, the relative evaluation weight of every item of different evaluation item is specified. First, the element of $C_{i}$ is established, where the subscript $i$ indicates the relative weight of the $i$-th evaluation weight error of total weight error and $i=1,2, \ldots, m$. The $C_{i}$ may be described by

$$
C_{i}=\left[\frac{\sum_{j=1}^{n}\left(b_{i j}-w_{j}\right)^{2}}{\sum_{i=1}^{m} \sum_{j=1}^{n}\left(b_{i j}-w_{j}\right)^{2}}\right]^{1 / 2}
$$

Second, we take through empirical formula

$$
d_{1}=\frac{1}{C_{i}}, \quad i=1,2, \ldots, m
$$

Finally, let

$$
\lambda_{i}=\frac{d_{i}}{\sum_{i=1}^{m} d_{i}}, \quad i=1,2, \ldots, m
$$

where $\lambda_{i}$ denotes the relative weight of the $i$-th $h_{m}$ evaluation member, and $\lambda_{i}$ should satisfy $0 \leq \lambda_{i} \leq 1, \sum_{i=1}^{m} \lambda_{i}=1$, and $\lambda=\left(\lambda_{1}, \lambda_{2}, \ldots, \lambda_{m}\right)$.

\section{Multiple objective and span evaluation method}

Based on the optimum weight and the relative evaluation weight of evaluation member established above, we may carry out the step of final evaluation. First, according to the relative specification of existing bridges, safe damage evaluation is performed on every evaluation member. The damage evaluation matrix is thus set up and described by

$$
R=\left[\begin{array}{cccc}
r_{11} & r_{12} & \cdots & r_{1 n} \\
r_{21} & r_{22} & \cdots & r_{2 n} \\
\vdots & \vdots & \ddots & \vdots \\
r_{m 1} & r_{m 2} & \cdots & r_{m n}
\end{array}\right]
$$

where $r_{i j}$ represents the results of damage evaluation of the ith evaluation member with respect to the jth evaluation item. The value of $r_{i j}$ is always normalized and satisfy $0 \leq r_{i j} \leq 1$. The higher the value, the more severe the damage degree. Second, the evaluation vector of evaluation member is established as

$$
E=R \cdot W^{T}=\left[\begin{array}{cccc}
r_{11} & r_{12} & \cdots & r_{1 n} \\
r_{21} & r_{22} & \cdots & r_{2 n} \\
\vdots & \vdots & \ddots & \vdots \\
r_{m 1} & r_{m 2} & \cdots & r_{m n}
\end{array}\right] \cdot\left[\begin{array}{c}
w_{1} \\
w_{2} \\
\vdots \\
w_{n}
\end{array}\right]=\left[\begin{array}{c}
e_{1} \\
e_{2} \\
\vdots \\
e_{n}
\end{array}\right]
$$

If the operational method of weight average type is adopted, then the evaluation vector of evaluation member can be expressed as

$$
E^{*}=E^{T}=\left[e_{1}, e_{2}, \ldots, e_{m}\right]
$$

where 


$$
e_{i}=\sum_{j=1}^{n} r_{i j} w_{j}
$$

Finally, the concept of weight average type is adopted. The synthesis damage evaluation of every evaluation member is set up as follows:

$$
U=E^{*} \cdot \lambda^{T}=\sum_{i=1}^{m} e_{i} \lambda_{i}
$$

Eq. (15) stands for the evaluation result of the multiple objective and span evaluation method. According to the evaluation criterion, the actual service state of existing structures can be determined.

\section{EVALUATION OF THE EXISTING REINFORCED CONCRETE BRIDGES USING THE MULTIPLE OBJECTIVE AND SPAN EVALUATION METHOD}

At present, the practical judgement method is usually adopted to evaluate existing structures. It is developed from the basis of traditional experience method. When the practical judgement method is applied to carry out the evaluation of structural performance, the investigation is generally needed three items. That is

a. Preliminary investigation: The overall structural condition is investigated. It includes structural scale, design data, employment variation, environment, structural type and judgenment purpose.

b. The foundation materials and members of existing structures should be studied.

c. The calculation and analysis of existing structures and the member or model test performed in the laboratory are necessarily probed.

During the evaluation task for actual structures, the practical judgement method is always combined with the traditional experience method for the purpose of promoting the investigation reliability.

The evaluation method of structural performance is firstly based on both the investigation, in-site test and experimental test with respect to structural system and the results of analysis and checking. The synthesis evaluation is then secondly carried out according to the current design specification and the evaluation grade standard relative reliability. Generally speaking, the structural system of existing reinforced concrete bridges can be divided into member and item for grade evaluation. The reliability grade evaluation of member represents grades $a, b, c$ and $d$. The reliability grade evaluation of item indicates grades I, II, III and IV.

The evaluation of structural performance is a kind of synthetic evaluation. The evaluation results are based on the result of investigation, measurement, test, analysis and calculation with respect to structural system and according to the current design specification and the relative reliability evaluation standard for carrying out synthetic evaluation. According to specification to perform the structural evaluation, the structural system is generally divided into member and item for in turn grade evaluation.

\section{Suppose that}

$$
V=\left\{V_{1}, V_{2}, \ldots, V_{n}\right\}
$$

is the damage state grade set of existing reinforced concrete bridges, where $V_{i}$ expresses the evaluation results of the damage degree obtained from every considered factor, in which $i=1,2, \ldots, n$. At present, the evaluation member of existing reinforced concrete bridges is partitioned into deck, girder and pier factors. Overall evaluation is performed on every factor such as outward appearance, cracks, and steel corrosion. To clearly provide the standard factor of $U$, the evaluation grades $a, b, c$ and $d$ of outward appearance, cracks, and steel corrosion are listed in Tables 1 to 3. For every considered factor, evaluation grade based on the specification and requirements of researchers and engineers can be divided into grades $a, b, c$ and $d$. That is

$$
V_{i} \in\{a, b, c, d\}
$$

where $V_{i}$ is the evaluation set of every factor. The descriptions of $a, b, c$ and $d$ mean the fuzzy grade of excellent, good, middle and bad, respectively. As it is difficult to have a specific border between grades, in the

Table 1. Evaluation grade of member outward appearance

\begin{tabular}{cllll}
\hline Evaluation grade & \multicolumn{1}{c}{$\mathrm{a}$} & \multicolumn{1}{c}{$\mathrm{b}$} & \multicolumn{1}{c}{$\mathrm{c}$} & $\mathrm{d}$ \\
\hline Description & External look is perfect & External look has some & External look has appeared & External look has \\
& without any damage. & pock-warked faces with & some concrete spalling with & appeared some \\
& & honeycomb due to bad & width $0.25 ~ 0.50 \mathrm{~mm}$ due to & concrete spalling \\
& & construction and has & steel corrosion. & above width $0.50 \mathrm{~mm}$ \\
& & & \\
& appeared some concretee & & due to steel corrosion. \\
& spalling due to steel & & \\
& corrosion. & & \\
\hline
\end{tabular}


Table 5. Evaluation grade of damage state of existing reinforced concrete bridges

\begin{tabular}{cl}
\hline Grade & \multicolumn{1}{c}{ Description } \\
\hline I & $\begin{array}{l}\text { With respect to bridge structure or its member, their appearances are very good. Both the rigidity and } \\
\text { supportability of member are above the safe load required by the design and are also satisfied the requirement } \\
\text { of current domestic specification. The durability of bridge is also enough and can be continuously used. } \\
\text { In respect to the bridge structure or its members, their appearances have some damages. Both the rigidity } \\
\text { and supportability of member tend to have decreased. However, they are still above the safe load required } \\
\text { by the design and are also satisfied the requirement of current domestic specification. The durability of bridge } \\
\text { appear a little problem. The bridge can be continuously used if it has been done a little scale repair. }\end{array}$ \\
II & $\begin{array}{l}\text { Concerning bridge structure or its members, their appearances have severe damage. Both the rigidity and } \\
\text { supportability of member have decreased. Part of the members have safety problems and their durability are } \\
\text { bad. The bridge can be continuously used if a large scale repair is performed or the service load is reduced. } \\
\text { III } \\
\text { As regards bridge structure or its member, their appearances have very severe damage. Both the rigidity and } \\
\text { supportability of member are not enough and are influenced the normal safe usage. The durability of bridge } \\
\text { is very bad. The rate of damage is fast. The bridge is unfit for service. }\end{array}$ \\
IV &
\end{tabular}

Table 2. Evaluation grade of cracked width for the members of reinforced concrete

\begin{tabular}{ccccc}
\hline $\begin{array}{c}\text { Evaluation } \\
\text { grade }\end{array}$ & $\mathrm{a}$ & $\mathrm{b}$ & $\mathrm{c}$ & $\mathrm{d}$ \\
\hline $\begin{array}{c}\text { Cracked width } \\
(\mathrm{mm})\end{array}$ & $<0.10$ & $0.10 \sim 0.25$ & $0.25 \sim 0.50$ & $>0.50$ \\
\hline
\end{tabular}

Table 3. Evaluation grade of steel corrosion

\begin{tabular}{ccccc}
\hline $\begin{array}{c}\text { Evaluation } \\
\text { grade }\end{array}$ & $\mathrm{a}$ & $\mathrm{b}$ & $\mathrm{c}$ & $\mathrm{d}$ \\
\hline$\frac{A^{*}}{A_{0}}$ & 0 & $\leq \frac{1}{6}$ & $\leq \frac{1}{3}$ & $>\frac{1}{3}$ \\
\hline
\end{tabular}

*: $A_{0}$-originally cross-sectional area of steel; $A$-cross-sectional area of steel after corrosion.

fuzzy evaluation, the membership degree of influence factors is always normalized for expression, that is

$$
V_{i} \in\{0,1\}
$$

In this paper, the grades $a, b, c$ and $d$ according to the normalization of fuzzy evaluation are shown in Table 4.

Similarly, the grade evaluation of item can be expressed as

$$
V_{i} \in\{\mathrm{I}, \mathrm{II}, \mathrm{III}, \mathrm{IV}\}
$$

where $V$ is the evaluation set of item. The description corresponding to evaluation grade is represented as in Table 5. The grades I, II, III and IV according to the normalization of fuzzy evaluation are listed in Table 6 .
Table 4. Membership degree of evaluation grade of member

\begin{tabular}{ccccc}
\hline Evaluation grade & $\mathrm{a}$ & $\mathrm{b}$ & $\mathrm{c}$ & $\mathrm{d}$ \\
\hline Membership degree & {$[0.00,0.25]$} & {$[0.25,0.50]$} & {$[0.50,0.75]$} & {$[0.75,1.00]$} \\
\hline
\end{tabular}

Table 6. Membership degree of evaluation grade of item

\begin{tabular}{ccccc}
\hline Evaluation grade & I & II & III & IV \\
\hline Membership degree & {$[0.00,0.25]$} & {$[0.25,0.50]$} & {$[0.50,0.75]$} & {$[0.75,1.00]$} \\
\hline
\end{tabular}

\section{ILLUSTRATIVE EXPAMLES}

With the view of combining theory with practice and verifying the serviceability of the multiple objective and span evaluation method, the Huey-tong bridge, Jzyh-chyang bridge, Ay-gwo west road viaduct and old Hwan-nan viaduct in Taipei were adopted for actual analyses. Before carrying out the analytical task, the overall structural conditions of the four bridges in Taipei are listed in Tables 7 to10. Table 11 shows one of the supportability preliminary evaluations of the Hueytong bridge. The other bridges also received the same preliminary evaluation. After understanding the data from the four bridges, the analytical tasks were performed. The Huey-tong bridge is now illustrated in the following:

First, the damage evaluation items of existing reinforced concrete bridges are divided into deck, girder and pier factors. As for the damage evaluation members, the values of 2, 4, 9 and 10 of damage evaluation members are adopted for the Huey-tong bridge, Jzyhchyang bridge, Ay-gwo west road viaduct and old Hwannan viaduct, respectively. The objective evaluation 
Table 7. Overall structural conditions of the Huey-tong bridge

\begin{tabular}{|c|c|}
\hline Item & Description \\
\hline $\begin{array}{l}\text { Date of completed } \\
\text { construction }\end{array}$ & $\begin{array}{l}\text { This bridge was completed in September, 1949. The expanded engineering of single side was } \\
\text { carried out in December, } 1957 .\end{array}$ \\
\hline $\begin{array}{l}\text { Bridge site Stridden } \\
\text { over waterway }\end{array}$ & $\begin{array}{l}\text { On the connection between 3rd. Section, Nanjing East Road and Hsin-sheng North Road. } \\
\text { Hsin-sheng line drainage }\end{array}$ \\
\hline $\begin{array}{l}\text { Simply structural } \\
\text { introduction }\end{array}$ & $\begin{array}{l}\text { 1. The original width of bridge floor is } 7.5 \mathrm{~m} \text {. The prestressed beam was expanded on the northern } \\
\text { side in } 1957 \text {. The width of bridge is } 24.5 \mathrm{~m} \text {. } \\
\text { 2. The net distance of I-type beam is } 1.65 \mathrm{~m} \text {. } \\
\text { 3. The rubber mats were used to support the I-type beams. }\end{array}$ \\
\hline $\begin{array}{l}\text { Prime survey and } \\
\text { evaluation by expert }\end{array}$ & $\begin{array}{l}\text { 1. Bridge floor equipment } \\
\text { a. Local cracks have occurred in parts of balustrade. } \\
\text { b. Some damage occurred in metal balustrade. } \\
\text { c. The expansion joints were covered by asphalt concrete. } \\
\text { d. Without drainage equipment. } \\
\text { 2. Superstructures } \\
\text { a. Cracks, concrete spalling, and steel corrosion occurred in the southern side of the arch bridge. } \\
\text { b. The split was occurred on the top of the arch bridge. } \\
\text { c. The concrete spalling and steel corrosion have occurred on the cantilever of deck of the arch } \\
\text { bridge. } \\
\text { 3. Substructures } \\
\text { a. Many cracks and local concrete spalling have occurred on bridge abutment. } \\
\text { b. Severe seepage situation occurred in the expansion joints of bridge abutment. } \\
\text { c. The metal mats supported the I-type beams were corroded. }\end{array}$ \\
\hline
\end{tabular}

Table 8. Overall structural conditions of the Jzyh-chyang bridge

\begin{tabular}{|c|c|}
\hline Item & Description \\
\hline $\begin{array}{l}\text { Date of completed } \\
\text { construction }\end{array}$ & This bridge was completed in 1972. \\
\hline Bridge site & Connect the Jzyh-chyang tunnel at the Shyh-lin exit with Guh-gong road. \\
\hline $\begin{array}{l}\text { Stridden over } \\
\text { waterway }\end{array}$ & The Way-shuang stream \\
\hline $\begin{array}{l}\text { Simply structural } \\
\text { introduction }\end{array}$ & $\begin{array}{l}\text { 1.The bridge floor was planned as one way for vehicular traffic and sidewalk. The width of bridge } \\
\text { deck is } 10.2 \mathrm{~m} \text {. } \\
\text { 2. The superstructure is two } 33 \mathrm{~m} \text { straddling simply supported prestressed I-type beam. } \\
\text { 3. The piers of substructures are doorframe types. } \\
\text { 4. The cast steel socket was used for support. } \\
\text { 5. The kind of expansion joint was made from steel. }\end{array}$ \\
\hline $\begin{array}{l}\text { Prime survey } \\
\text { and evaluation } \\
\text { by expert }\end{array}$ & $\begin{array}{l}\text { 1. Bridge floor equipment } \\
\text { a. Local concrete spalling occurred on balustrade. Local damage of aluminium balustrade was happen. } \\
\text { b. Some expansion joints were damaged or were covered by asphalt concrete. } \\
\text { c. Local pavement with asphalt concrete is not steady and smooth. It easily influences the comfort } \\
\text { movement of vehicles. } \\
\text { d. The concrete on sidewalk in east line has local spalling . } \\
\text { e. The drain weeps were set up for drain tile. The drain water directly flow down along girders. } \\
\text { 2. Superstructures } \\
\text { a. A part of prestressed beam has concrete spalling and honeycomb situations. } \\
\text { b. Both bridge deck and separated been have local concrete spalling, honeycomb, and steel corrosion } \\
\text { situations. } \\
\text { 3. Substructures } \\
\text { a. Column supported piers have local concrete spalling, steel Corrosion, and cracks. } \\
\text { b. The hinges made with steel for supported girder are severely corroded. } \\
\text { c. The capbeams in east line have local concrete spalling and steel exposures situation while the } \\
\text { capbeams in west line also have severe concrete spalling, steel exposure, and cracks situations. } \\
\text { d. Concrete remnants due to replaced expansion joint were discovered on the top of bridge abutment } \\
\text { and capbeam. }\end{array}$ \\
\hline
\end{tabular}


Table 9. Overall structural conditions of the Ay-gwo west road viaduct

\begin{tabular}{|c|c|}
\hline Item & Description \\
\hline $\begin{array}{l}\text { Date of completed } \\
\text { construction }\end{array}$ & This viaduct was completed in 1983 . \\
\hline viaduct site & $\begin{array}{l}\text { Locates on the Ay-gwo west road. Strides over Yan-pyng south road and the circle of Jong-haw road. } \\
\text { Fork at Jong-haw road and connect to Guey-lin road and Nor-ling road. }\end{array}$ \\
\hline $\begin{array}{l}\text { Stridden over } \\
\text { junction road }\end{array}$ & This viaduct strides over Yan-pyn south road and the circle of Jong-haw road. \\
\hline Simply structural & $\begin{array}{l}\text { 1. Bridge deck: a. connected Ay-gwo west road with } 22.1 \mathrm{~m} \text {; b. connected Nan-Ning road with } \\
16.1 \mathrm{~m} \text {; c. connected Guey-lin road with } 8.1 \mathrm{~m} \text { width. } \\
\text { 2. Structural type: a. two or three straddling of continuonsly prestressed box beam; b. composite box } \\
\text { steel for simple support. } \\
\text { 3. Substructures are made of concrete: a. piers consist of three columns; b. Doorframe piers composed } \\
\text { two to four columns. } \\
\text { 4. The bridge abutment is a kind of cantilever type. } \\
\text { 5. Foundation type: a. prestressed concrete pile; b. steel-pipe pile; c. reverse circulation pile. } \\
\text { 6. Supported type: a. rubber support; b. steel support. } \\
\text { 7. The expansion joint is modular type. }\end{array}$ \\
\hline $\begin{array}{l}\text { Prime survey and } \\
\text { evaluation by expert }\end{array}$ & $\begin{array}{l}\text { 1. Bridge floor equipment } \\
\text { a. The breast walls of all lines have steel corrosion and concrete spalling; b. The expansion joints of } \\
\text { bridge floor have seepage. The substructures suffered long-term erosion; c. The drain weeps of } \\
\text { guideway had widespread blockage. } \\
\text { 2. Superstructures } \\
\text { a. The bottoms of prestressed box beam have not enough concrete covering and have local concrete } \\
\text { spalling. Beam bottom near capbeam has many cracks; b. The steel beam stridden over Jong-hwa } \\
\text { road has severe corrosion due to seepage from upper expansion joints and joints; c. The bridge floor } \\
\text { of concrete box beam has concrete spalling cracks and specks. } \\
\text { 3. Substructures } \\
\text { a. The top of pier without capbeam has obvious cracks; b. The expansion joints of bridge floor has } \\
\text { severe seepage. This easily occurs as a mass on the top of capbeam and the corrosion of supported } \\
\text { steel; c. The capbeams all have cracks and local concrete spalling and steel exposure. }\end{array}$ \\
\hline
\end{tabular}

Table 10. Overall structural conditions of the old Hwan-nan viaduct

\begin{tabular}{|c|c|}
\hline Item & Description \\
\hline $\begin{array}{l}\text { Date of completed } \\
\text { construction }\end{array}$ & This viaduct was complated in 1974. The replaced engineering was completed in 1988. \\
\hline viaduct site & $\begin{array}{l}\text { Located on Hwan-her south road. This road surface is located on the northern of Jong-shiaw west road } \\
\text { and south of Guey-lin road. }\end{array}$ \\
\hline $\begin{array}{l}\text { Stridden over } \\
\text { junction viaduct }\end{array}$ & Viaduct \\
\hline $\begin{array}{l}\text { Simply structural } \\
\text { introduction }\end{array}$ & $\begin{array}{l}\text { 1. Bridge width is } 7 \mathrm{~m} \text {. } \\
\text { 2. Superstructures : a. Box beam with no quilibrium cantilever plate. b. Densely arrange the rectangular hollow } \\
\text { made from precast prestressed concrete. c. Closely arrange I-type beam made from precast prestressed concrete. } \\
\text { d. Hollow plate-beam made from field cast concrete. e. Solid plate-beam made } \\
\text { from field cast concrete. } \\
\text { 3. Substructures: a. Single-column pier, b. camp pier. } \\
\text { 4. Supported type: a. rubber mats for support, b. steel mats for support, c. Connected with column. }\end{array}$ \\
\hline $\begin{array}{l}\text { Prime survey and } \\
\text { evaluation by } \\
\text { expert }\end{array}$ & $\begin{array}{l}\text { 1. Bridge floor equipment } \\
\text { a. All line rails have damage, steel corrosion, and concrete spalling. The breast walls of the outside } \\
\text { carriage way have obviously not enough concrete covering induced steel exposure. } \\
\text { b. The seepage of all line expansion joints results from a mass on the top of capbeam and corrosion at supported } \\
\text { steel plate. The expansion joints of parts of road section were covered by asphalt concrete and were loss } \\
\text { function. } \\
\text { c. The pavements of all line asphalt concrete are damaged and have accumulated water. } \\
\text { d. The drain weeps of guideway had widespread blockage and were loss function } \\
\text { e. A part of stair has concrete spalling and steel exposuse and corrosion. } \\
\text { 2. Superstructures } \\
\text { a. The outside bottoms of bridge floor of old viaduct have not enough cover thickness for steel. } \\
\text { b. The bottom of parts of girder have concrete spalling and steel exposure and corrosion. } \\
\text { 3. Substructures } \\
\text { a. The column supported pier and capbeam of old viaduct have obviously cracks, seepage, and white } \\
\text { specks phenomena. } \\
\text { b. A large mass was located on the top of capbeam. This Easily occurs in degeneration of rubber mats. }\end{array}$ \\
\hline
\end{tabular}




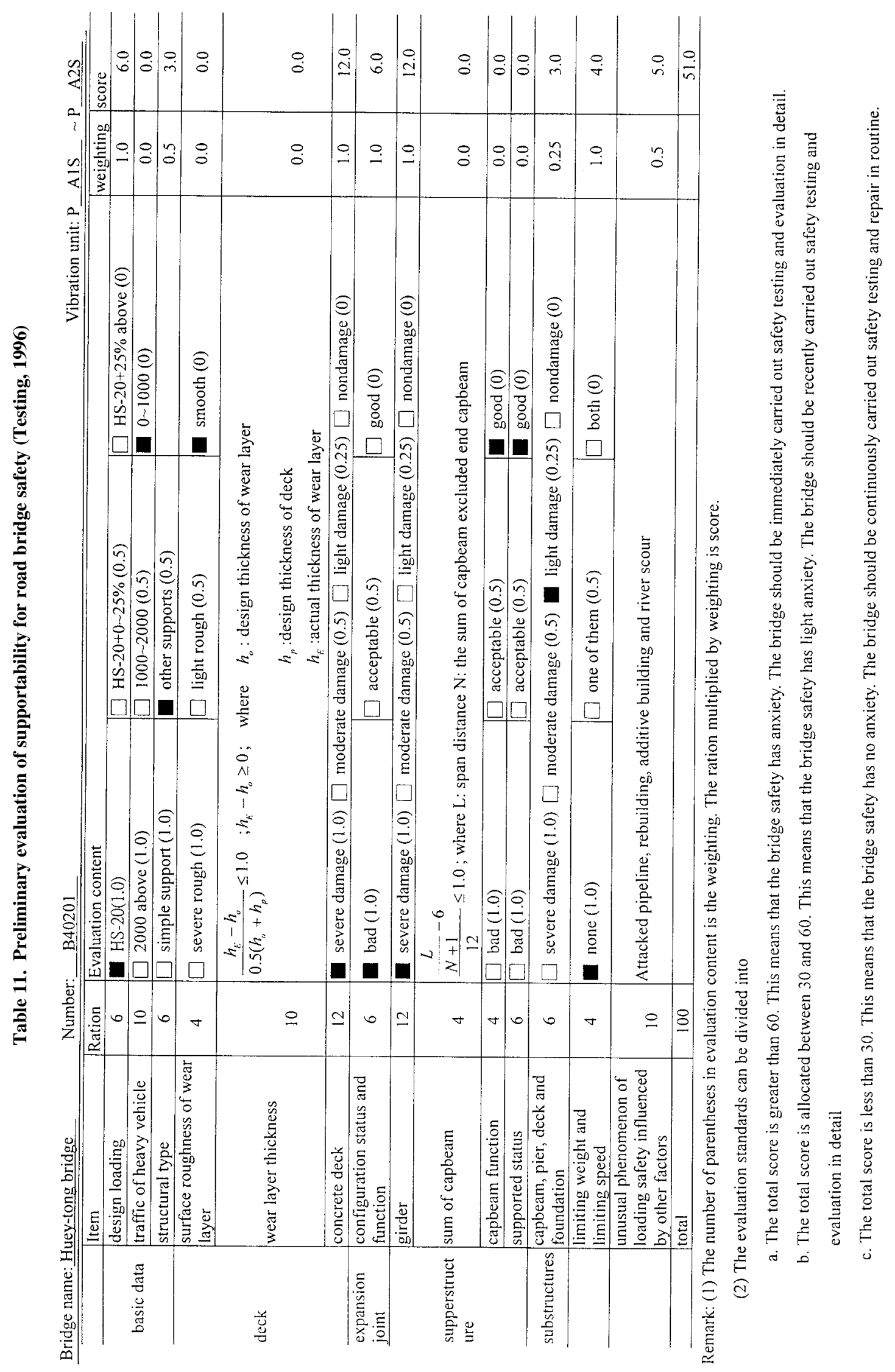


matrix, A (Ref. Tables 2 and 3), and the guide specification evaluation matrix, $\mathrm{R}$ (Ref. Tables 5, 6 and 11), of the four bridges are also established as shown in Table 12. From Table 12, we know that the objective evaluation matrix of the Huey-tong bridge is

$$
A=\left[\begin{array}{ccc}
0.7 & 0.75 & 0.15 \\
0.2 & 0.1 & 0.4
\end{array}\right]
$$

After normalizing A, we obtain the objective relative evaluation matrix

$$
B=\left[\begin{array}{lll}
0.4375 & 0.4687 & 0.0938 \\
0.2857 & 0.1429 & 0.5714
\end{array}\right]
$$

Based on the data of evaluation results as shown in Table 11, the guide specification evaluation matrix is set up:

$$
R=\left[\begin{array}{llc}
0.75 & 0.75 & 0.25 \\
0.25 & 0.25 & 0.5
\end{array}\right]
$$

Table 12. Objective evaluation matrix and guide specification evaluation matrix of four bridges in Taipei

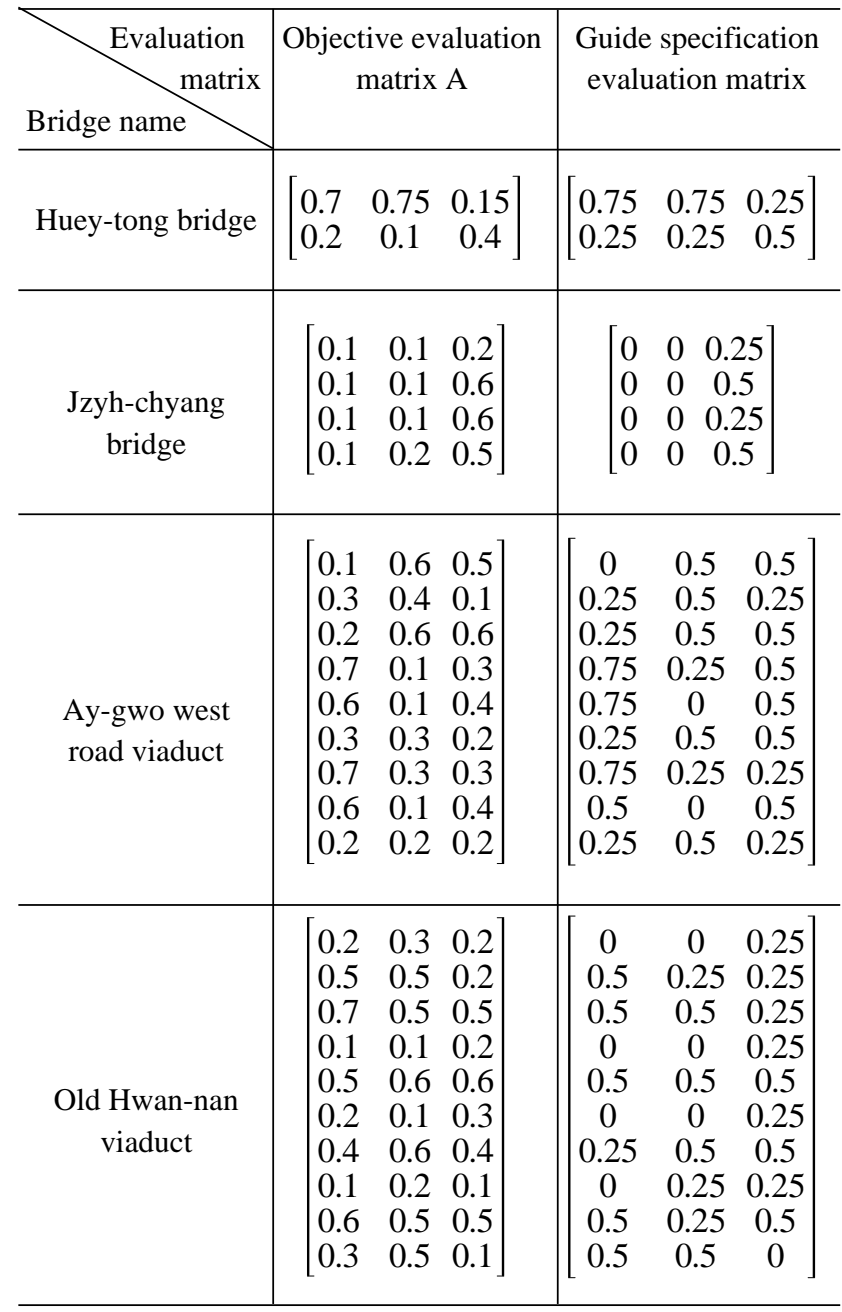

Second, from Eqs. (4)-(6), the best weight is built:

$$
W=\left[\begin{array}{lll}
0.3616 & 0.3058 & 0.3326
\end{array}\right]
$$

Through Eqs. (7)-(10), the relative evaluation weight of bridge spans is determined:

$$
\lambda=\left[\begin{array}{ll}
0.5 & 0.5
\end{array}\right]
$$

Using Eqs. (11)-(13), the synthetic evaluation vector of bridge span is firmly established:

$$
E^{*}=\left[\begin{array}{ll}
0.5837 & 0.33315
\end{array}\right]
$$

Finally, from Eq. (15), the synthetic damage evaluation using the multiple objective and span evaluation method is obtained:

$$
U=E^{*} \cdot \lambda^{T}=0.4584
$$

The value of $U$ mentioned above is located in $[0.50,0.25]$. This means that the evaluation results using the proposed method for the Huey-tong bridge belong to the grade II. It is pointed out that the Hueytong bridge has light damage. However, if periodic small scale repair and reinforcement are carried out, the Huey-tong bridge can be continuously used. Similarly, the Jzyh-chyang bridge, Ay-gwo west road viaduct and old Hwan-nan viaduct are evaluated by the proposed method. The values of $w, \lambda, E^{*}$ and $U$ of the four bridges are listed in Tables 13-17. From Table 17, we know that the values of $U$ of the Jzyh-chyang bridge, Ay-gwo west road viaduct and old Hwan-nan viaduct are 0.2644, 0.3839 and 0.3248 , respectively, and all are located in $[0.25,0.50]$. It is obvious that the three bridges belong to the grade II.

\section{DISCUSSION}

A bridge usually has many spans. The bridge in a

Table 13. Multiple objective relation weight, multiple member relative evaluation weight and member synthesis evaluation vector of the Huey-tong bridge

\begin{tabular}{l|c}
\hline \multicolumn{1}{c|}{ Bridge name } & Huey-tong bridge \\
\hline $\begin{array}{l}\text { Evaluation item } \\
\text { weight } W\end{array}$ & {$\left[\begin{array}{lll}0.3616 & 0.3058 & 0.3326\end{array}\right]$} \\
\hline $\begin{array}{l}\text { Multiple member relative } \\
\text { evaluation weight } \lambda\end{array}$ & {$\left[\begin{array}{ll}0.5 & 0.5\end{array}\right]$} \\
\hline $\begin{array}{l}\text { Member synthesis evaluation } \\
\text { vector } E^{*}\end{array}$ & {$\left[\begin{array}{lll}0.5837 & 0.33315\end{array}\right]$} \\
\hline
\end{tabular}


Table 14. Multiple objective relation weight, multiple member relative evaluation weight and member synthesis evaluation vector of the Jzyh-chyang bridge

\begin{tabular}{|c|c|}
\hline $\begin{array}{l}\text { Bridge name } \\
\text { Evaluation item }\end{array}$ & Jzyh-chyang bridge \\
\hline $\begin{array}{l}\text { Multiple objective relation } \\
\text { weight } W\end{array}$ & {$\left[\begin{array}{lll}0.15625 & 0.1875 & 0.65625\end{array}\right]$} \\
\hline $\begin{array}{l}\text { Multiple member relative } \\
\text { evaluation weight } \lambda\end{array}$ & {$\left[\begin{array}{l}0.146808 \\
0.241867 \\
0.241867 \\
0.369458\end{array}\right]^{T}$} \\
\hline $\begin{array}{l}\text { Member synthesis } \\
\text { evaluation vector } E^{*}\end{array}$ & {$\left[\begin{array}{l}0.164063 \\
0.328125 \\
0.164063 \\
0.328125\end{array}\right]^{T}$} \\
\hline
\end{tabular}

Table 15. Multiple objective relation weight, multiple member relative evaluation weight and member synthesis evaluation vector of the Ay-gwo west road viaduct

\begin{tabular}{|c|c|}
\hline Evaluation item & Ay-gwo west road viaduct \\
\hline $\begin{array}{l}\text { Multiple objective } \\
\text { relation weight } W\end{array}$ & {$\left[\begin{array}{lll}0.3973 & 0.2934 & 0.3096\end{array}\right]$} \\
\hline $\begin{array}{l}\text { Multiple member relative } \\
\text { evaluation weight } \lambda\end{array}$ & {$\left[\begin{array}{l}0.052787 \\
0.074326 \\
0.066282 \\
0.065481 \\
0.080486 \\
0.199641 \\
0.119138 \\
0.080486 \\
0.261372\end{array}\right]^{T}$} \\
\hline $\begin{array}{l}\text { Member synthesis evaluation } \\
\text { vector } E^{*}\end{array}$ & {$\left[\begin{array}{c}0.301484 \\
0.323403 \\
0.4008 \\
0.526089 \\
0.452745 \\
0.4008 \\
0.448692 \\
0.353428 \\
0.323403\end{array}\right]^{T}$} \\
\hline
\end{tabular}

span includes many members. Hence, the task of evaluation damage of existing reinforced concrete bridges is really not only a thorny subject but also a fuzzy topic. As for evaluating a bridge, it is certainly difficult to evaluate every member. If every member of a bridge
Table 16. Multiple objective relation weight, multiple member relative evaluation weight and member synthesis evaluation vector of the old Hwan-nan viaduct

\begin{tabular}{|c|c|}
\hline $\begin{array}{l}\text { Bridge name } \\
\text { Evaluation item }\end{array}$ & Old Hwan-nan viaduct \\
\hline $\begin{array}{l}\text { Multiple objective } \\
\text { relation weight } W\end{array}$ & {$\left[\begin{array}{lll}0.323556 & 0.370567 & 0.305876\end{array}\right]$} \\
\hline $\begin{array}{l}\text { Multiple member relative } \\
\text { evaluation weight } \lambda\end{array}$ & {$\left[\begin{array}{c}0.154425 \\
0.064171 \\
0.09496 \\
0.046422 \\
0.191293 \\
0.39564 \\
0.154494 \\
0.070084 \\
0.143133 \\
0.041455\end{array}\right]^{T}$} \\
\hline $\begin{array}{l}\text { Member synthesis } \\
\text { evaluation vector } E^{*}\end{array}$ & {$\left[\begin{array}{c}0.076469 \\
0.330889 \\
0.423531 \\
0.076469 \\
0.5 \\
0.076469 \\
0.419111 \\
0.169111 \\
0.407358 \\
0.347062\end{array}\right]^{T}$} \\
\hline
\end{tabular}

were evaluated, then three problems arise, i.e., (1) It is not followed economic effect. (2) Not all members can be cored specimen for testing. (3) Although some members have severe damage, they may not occur the safe problem to existing bridge. On these accounts, when we evaluate the bridge damage, the most important evaluation member and item are taken for determining the evaluation data.

For the purpose of proving the serviceability and reliability of the proposed method, the evaluation results of the proposed method for the four bridges in Taipei are compared with those results obtained by Liang et al. $(2000,2001)$ and are shown in Table 17. In the case of the evaluation result of the Huey-tong bridge from Table 17, the result obtained by Liang et al. (2000) shows that the damage membership degree of the Hueytong bridge located in grade I and II reaches 0.634. However, the result obtained by Liang et al. (2001) reveals that the damage membership degree of the Hueytong bridge allocated in grade II and III is large. This means that the damage degree of the Huey-tong bridge is located in the interval between light and moderate damage. On the other hand, the evaluation value of $U$ obtained from the proposed method with respect to the 
Table 17. Comparison of proposed and Liang et al. [2000, 2001] results of damage evaluation for four bridges in Taipei

\begin{tabular}{|c|c|c|c|}
\hline $\begin{array}{r}\begin{array}{r}\text { Evaluation } \\
\text { method }\end{array} \\
\text { Membership } \\
\text { degree }\end{array}$ & Proposed method & $\begin{array}{l}\text { Multiple-layer fuzzy } \\
\text { evaluation method } \\
\text { [Liang } \text { et al. 2001] }\end{array}$ & $\begin{array}{c}\text { Double-layer } \\
\text { synthesis evaluation } \\
\text { method [Liang et al. 2000] }\end{array}$ \\
\hline $\begin{array}{c}\text { Huey-tong } \\
\text { bridge }\end{array}$ & $\begin{array}{l}\text { membership degree } \\
\text { U: } 0.4584 \\
\text { grade: II }\end{array}$ & $\begin{array}{l}\text { I: } 0.186 \\
\text { II: } 0.293 \\
\text { III: } 0.288 \\
\text { IV: } 0.140 \\
\text { V: } 0.093\end{array}$ & $\begin{array}{l}\text { I: } 0.334 \\
\text { II: } 0.300 \\
\text { III: } 0.191 \\
\text { IV: } 0.175\end{array}$ \\
\hline $\begin{array}{c}\text { Jzyh-chyang } \\
\text { bridge }\end{array}$ & $\begin{array}{l}\text { membership degree } \\
\text { U: } 0.2644 \\
\text { grade: II }\end{array}$ & $\begin{array}{l}\text { I: } 0.174 \\
\text { II: } 0.344 \\
\text { III: } 0.308 \\
\text { IV: } 0.174 \\
\text { V: } 0.000\end{array}$ & $\begin{array}{l}\text { I: } 0.410 \\
\text { II: } 0.337 \\
\text { III: } 0.168 \\
\text { IV: } 0.085\end{array}$ \\
\hline $\begin{array}{l}\text { Ay-gwo west } \\
\text { road viaduct }\end{array}$ & $\begin{array}{l}\text { membership degree } \\
\text { U: } 0.3839 \\
\text { grade: II }\end{array}$ & $\begin{array}{l}\text { I: } 0.194 \\
\text { II: } 0.306 \\
\text { III: } 0.312 \\
\text { IV: } 0.094 \\
\text { V: } 0.094\end{array}$ & $\begin{array}{l}\text { I: } 0.363 \\
\text { II: } 0.326 \\
\text { III: } 0.193 \\
\text { IV: } 0.118\end{array}$ \\
\hline $\begin{array}{l}\text { Old Hwan-nan } \\
\text { viaduct }\end{array}$ & $\begin{array}{l}\text { membership degree } \\
\text { U: } 0.3248 \\
\text { grade: II }\end{array}$ & $\begin{array}{l}\text { I: } 0.202 \\
\text { II: } 0.291 \\
\text { III: } 0.324 \\
\text { IV: } 0.109 \\
\text { V: } 0.073\end{array}$ & $\begin{array}{l}\text { I: } 0.354 \\
\text { II: } 0.354 \\
\text { III: } 0.198 \\
\text { IV: } 0.094\end{array}$ \\
\hline
\end{tabular}

Huey-tong bridge is 0.4584 which is located in [0.25, $0.5]$ and is attributed to grade II. As we know that using different evaluation methods gain different evaluation grades, the evaluation results obtained from the three methods stated above for the Huey-tong bridge are closely approached. This reveals that the Huey-tong bridge has light or moderate damage. It can be continuously used if small scale repair or reinforcement is performed. As in the illustration and verification of the Huey-tong bridge, similar results for the Jzyh-chyang bridge, Ay-gwo west road viaduct and old Hwan-nan viaduct were obtained and are listed in Table 17. Through this investigation, it is worthy to point out that the proposed method is not only serviceable but also reliable.

The research makes a step toward developing an effective approach for evaluating the supportability of existing reinforced concrete bridges. More research is called for concerning the effectiveness of the antiseismic ability for road bridge safety in Taipei. In addition, there is a critical need for other methods in weight so that effective strategies currently being used by civil engineers to promote the proficiency of evaluation bridge damage can be identified.

\section{CONCLUSIONS}

The fuzzy mathematics with multiple objective and span evaluation method has been described. This proposed method was applied to evaluate the damage grade for four existing reinforced bridges in Taipei. The results of this investigation denote that the structural performance of the Huey-tong bridge, Jzyh-chyang bridge, Ay-gwo west road viaduct and old Hwan-nan viaduct belong to grade II which have membership degrees, $U$, of $0.4584,0.2644,0.3839$ and 0.3248 , respectively. Based on the membership degrees, the order repair and reinforcement about the four existing reinforced concrete bridges in Taipei is in turn suggested as follows: the Huey-tong bridge, Ay-gwo west road viaduct, old Hwan-nan viaduct and Jzyh-chyang bridge. Consequently, the proposed method has an advantage for evaluating the damage grade of existing reinforced concrete bridges.

\section{ACKNOWLEDGMENT}

The authors would like to thank to the National 
Science Council of the R. O. C. for financial support of this study under Contract NSC 89-2211-E-019-015.

\section{REFERENCES}

1. Jwu, T. H., Harn, Y., and Liou, W. M., Fuzzy Evaluation of Reliability of Wharf Structure at Harbor, Report of Investigation of Corrosion Failure and Its Protection Strategy of Harbor Wharf, Institute of Engineering and Technology of Ten-Jin Waterway, Department of Transportation, 10pp (1991). (in Chinese).

2. Liang, M. T., Wu, J. H., and Liang, C. H., “Applying Fuzzy Mathematics to Evaluation the Membership of Existing Reinforced Concrete Bridges in Taipei," Journal of Marine Science and Technology, Vol. 8, No. 1, 1629 (2000).

3. Liang, M. T., Wu, J. H., and Liang, C. H., "Multiple Layer Fuzzy Evaluation for Existing Reinforced Concrete Bridges," Journal of Infrastructure Systems, ASCE, Vol. 7, No. 4, 144-159 (2001).

4. Mori, Y., and Ellingwood, B. R., "Reliability-blased service-life assessment of aging concrete structures." $J$. Struct. Engrg., ASCE, Vol. 119, No. 5, 1600-1621 (1993).

5. Mori, Y., and Ellingwood, B. R., " Maintaining reliability of concrete structures. I: role of inspection/ repair." J. Struct. Engrg., ASCE, Vol. 120, No. 3, 824-845 (1994a).

6. Mori, Y., and Ellingwood, B. R., " Maintaining reliability of concrete structures. II: optimum inspection/ repair. " J. Struct. Engrg., ASCE, Vol. 120, No. 3, 846-862 (1994b).

7. Moses, F., Lebet, J. P., and Bez, R., "Application of field testing to bridge evaluation." J. Struct. Engrg., ASCE, Vol. 120, No. 6, 1745-1762 (1994).

8. Qu, W. J., Durability Estimation and Service Life Prediction of Existing Concrete Bridges, $\mathrm{Ph}$. D. Dissertation, Southwest Chiaotung University, China, 91-101 (1995) (in Chinese).

9. Qian, Y., J., Evaluation and diagnosis of existing reinforced concrete bridges, Ph. D. Dissertation, Southwest Chiaotung University, Xian, (1992) (in Chinese).

10. Shiaw, S. S., and Huang, W. D., "Synthesis Evaluation of Fuzzy and Random Properties for Bridge Bearing Capacity," Journal of Chiaotung Institute at ChungChing, Vol. 1, 64-71 (1990) (in Chinese).

11. Tharmabala, T. and Nowak, A. S., "Mathematical Models for Bridge Reliability," Canadian Journal of Civil Engineering, Vol. 14, 155-162 (1987).

12. Tee. A. B., Browan, M. D. and Sinha, K. C., "A fuzzy mathematical approach in condition assessment of highway bridges." Civil Engineering, Vol. 15, No. 1, 17-24 (1988).

13. Tee. A. B., The application of fuzzy mathematics to bridge condition assessment, Ph. D. Dissertation, Purdue University (1988).

14. Testing evaluation of road bridge, Taiwan Construction Research Institute, Taipei, Taiwan (1996).

15. Wang, G. Y., Theory of Soft Design in Engineering, Science Publisher, Beijing, 70-102 (1992) (in Chinese).
16. Wang. H. D., Basic Study on Durability Evaluation of Reinforced Concrete Structure, Ph. D. Dissertation, Department of Civil Engineering, Dalian University of Technology, China, 83-92. (1996) (in Chinese).

17. Yao, J. T. P., "Damage Assessment and Reliability Evaluation of Existing Structures," Journal of Engineering Structures, Vol. 1, 245-251 (1979).

18. Yao, J. T. P., Safety and Reliability of Existing Structures, Pitmen Advanced Publishing Program, London, 129pp (1985).

19. Zadeh, L. A., "Fuzzy Sets," Information and Control, Vol. 8, 338-353 (1965).

20. Zadeh, L. A., "Fuzzy Sets As a Basis for a Theory of Possibility," Fuzzy Sets and System, Vol. 1, No. 1, 3-28 (1978).

21. Zadeh, L. A., "A Theory of Approximate Reasoning," Machine Intelligence (Hayes, J. E., Michic, D., Mikulich, L. I. Ed.), Vol. 9 , 149-194 (1979).

22. Zhao, G. F., Reliability Theory of Engineering Structures and Its Application, Dalian Institute of Science and Technology Publisher, Dalian, China, 290-294 (1996) (in Chinese).

\section{多目標與跨度評估法預測既有銅筋 混凝土橋樑之損傷等级}

$$
\text { 梁明德吳家合 }
$$

國立台灣海洋大學河海工程學系

$$
\text { 王恆棟 }
$$

上海市政府工程設計研究院第二給水與排水部

$$
\text { 摘 要 }
$$

本文的主要目的是評估既有鋼筋混凝土橋樑的 使用性能, 採用經典數學中最小平方技巧建立多目標 加權分佈法與多跨度加權法, 這樣即可使用此法評估 既有鋼筋混凝土橋樑的使用性能, 評估損傷等級分爲 I, II, III及IV, 分別表示爲無損傷, 輕度損傷, 嚴 重損傷及不適用。應用本文建立之方法評估台北市既 有的惠通橋, 自強橋, 愛國西路高架橋及舊環南高架 橋等四座橋, 評估結果顯示此四座橋樑均屬於第II損 傷等級, 若週期性小規模維修和加固, 則此四座橋樑 均可繼續使用, 而維修與加固的順序爲惠通橋, 愛國 西路高架橋, 舊環南高架橋和自強橋, 顯然, 多目標 與跨度評估法具有評估既有鋼筋混凝土橋樑的優點。 研究結果可提供作爲既有鋼筋混凝土橋樑維修、加固 或拆除的依據。 